\title{
REVIEW
}

\section{Shark nursery areas: concepts, definition, characterization and assumptions}

\author{
Michelle R. Heupel ${ }^{1, *}$, John K. Carlson ${ }^{2}$, Colin A. Simpfendorfer ${ }^{3}$ \\ ${ }^{1}$ Center for Shark Research, Mote Marine Laboratory, 1600 Ken Thompson Parkway, Sarasota, Florida 34236, USA \\ ${ }^{2}$ NOAA, National Marine Fisheries Service, Southeast Fisheries Science Center, 3500 Delwood Beach Road, Panama City, \\ Florida 32408, USA \\ ${ }^{3}$ School of Earth and Environmental Sciences, James Cook University, Queensland 4811, Australia
}

\begin{abstract}
The concept of elasmobranch species using nursery areas was introduced in the early 1900s and has been an accepted aspect of shark biology and behavior for several decades. Despite several descriptions of how shark species use nursery areas and what types of regions nurseries may be found in, no explicit definition of what constitutes a shark nursery area has been presented. Here we evaluate the assumptions of the current shark nursery paradigm in light of available data. Based on examination of these assumptions and available methods of quantifying and accurately describing shark nursery areas, a new more quantitative definition of shark nursery areas is proposed. This definition requires 3 criteria to be met for an area to be identified as a nursery: (1) sharks are more commonly encountered in the area than other areas; (2) sharks have a tendency to remain or return for extended periods; and (3) the area or habitat is repeatedly used across years. These criteria make the definition of shark nursery areas more compatible with those for other aquatic species. The improved definition of this concept will provide more valuable information for fisheries managers and shark biologists.
\end{abstract}

KEY WORDS: Nursery area $\cdot$ Shark $\cdot$ Habitat $\cdot$ Definition

\section{INTRODUCTION}

The concept of nursery areas in shark populations (historically defined as regions where young are born or reside as they grow towards maturity) has been recognized in the scientific literature for nearly a century (unless otherwise specified, the term 'shark' is used to include all chondrychthyan fish species-i.e. sharks, rays, skates, sawfishes and chimaeras). Since its introduction it has become widely used, and considerable research effort has been expended on identifying these areas and better understanding their importance. While the concept of shark nursery areas is widely used, the literature lacks clear criteria for identifying a nursery area, making it impossible to consistently determine the occurrence of these regions.

The importance of identifying shark nursery areas has increased in recent decades as declines in shark populations have become more commonplace (Fowler et al. 2005) and management or conservation measures have needed to be implemented. For example, research on shark nursery areas in US territorial waters has increased (McCandless et al. in press) concomitant with both the decline-due to overfishing of some shark populations (NMFS 2006) and with the current mandate to incorporate Essential Fish Habitat (EFH) in all Fishery Management Plans (NOAA 1996). The increased use of EFH in management plans has recognized that all stages in a species life cycle are important, not just those stages vulnerable to exploitation. Thus better understanding of those habitats or regions that serve as nurseries should improve shark conservation and management (NMFS 2006). However, the development of appropriate management for nursery areas relies on the ability to accurately identify those areas that are of greatest importance. At present, 
weak definition of the shark nursery area concept means that such identification and prioritization is difficult, if not impossible.

The lack of methods to define and identify nursery areas is not restricted to sharks. Beck et al. (2001) identified the problem more generally in aquatic organisms and also provided a framework by which nursery areas could be assessed. These authors pointed out that estuarine and marine ecosystems are often referred to as nurseries although the nursery-role concept has rarely been stated clearly or tested. They defined a nursery as a region where juvenile fish occur at higher densities, avoid predation more successfully, grow at a faster rate than in other habitats and so provide a greater relative contribution to adult recruitment, than other areas. Such a definition means that not all areas where juveniles occur can be considered nursery areas, only those that make a proportionally greater contribution to the adult stock than the average.

In the years since the publication of Beck et al. (2001) the approach advocated has been embraced by teleost and invertebrate researchers and has been applied in a variety of studies (e.g. Heck et al. 2003, Stoner 2003, Kraus \& Secor 2005, Bethea et al. 2006). However, within the shark literature, the definition by Beck et al. (2001) has gone almost unnoticed and the use of the term 'shark nursery area' by a wide array of scientists, resource managers, and conservationists appears to be inconsistent and lacks proper scientific analysis and justification. In some cases regions are labeled shark nurseries simply because of the presence of a few juvenile sharks. Designation based on such limited data threatens to undermine the importance of protecting EFH by potentially identifying all coastal waters as shark nurseries.

Strict application of the definition of a nursery area from Beck et al. (2001), however, is difficult. For example, Kraus \& Secor (2005) attempted to apply the revised nursery-role concept to white perch Morone americana using otolith microchemistry. Although they noted the value of the points made by Beck et al. (2001), they also concluded that empirical testing of the nursery-role concept can be difficult and clouded by inter-annual variability in populations. This observation demonstrated that a strict definition of the nursery-role concept can be difficult to apply. Beck et al. (2001) recognized this problem, noting that some habitats are likely to serve as nursery areas even though there is no definitive test to delineate their contribution to the adult population. Such a discrepancy between the definition and the ability to practically apply it to specific areas means that nursery areas would potentially be identified only in rare situations, and so their protection through EFH or other conservation regimes would be limited.
To promote some consistency with which the term shark nursery area is used, and so help improve the identification and protection of $\mathrm{EFH}$, we review the history of the concept and propose a clear definition of the term that is consistent with theoretical considerations while allowing practical application. In addition, consideration is given to: (1) what data may appropriately be used to identify a shark nursery area; (2) the validity of some assumptions that are made concerning shark nursery areas; and (3) future directions for nursery area research that will improve the concept.

\section{HISTORY OF THE CONCEPT}

The concept of shark nurseries arose in several early studies that summarized observations on the general organization of shark populations. Although these concepts have been carried forward, they were all based on observations not designed for examining shark nursery function. Originally, Meek (1916) reported that shallow coastal waters were important nursery areas based on observations of pupping of 2 carcharhiniform sharks (Galeorhinus sp. and Mustelus sp.). Olsen (1954) reported nursery areas of the school shark Galeorhinus galeus in southern Australia, but like Meek (1916) did not consider them in any detail. Springer (1938, 1960, 1967) made comments regarding coastal shark species based on his observations along the east coast of the United States over several decades. He framed his comments in the context of a generalized shark species and did not intend them to describe any species in particular:

'In this hypothetical population, the young are born in the spring or early summer on specific nursery grounds that are in somewhat shallower waters than adults of the population usually frequent... The young in the hypothetical population remain in the vicinity of the nursery grounds while feeding and growing to sexual maturity but may move from the area if forced to do so by seasonal temperature changes.' (Springer 1967, p. 153)

Most researchers who study coastal shark species agree with the observations made by Springer (1967), although no definition of what constitutes a nursery area was laid out in his description. He did, however, consider the evolutionary significance when he observed that: 'The availability of nursery areas, not only suitable to each species but also comparatively free of predation by larger sharks, is very important in interspecies competition' (Springer 1967, p. 159).

Bass (1978) built on Springer's description based on prior observations of sharks in southern Africa (Bass et 
al. 1973, 1975) by suggesting that juvenile sharks may have 2 types of nursery areas:

'An interesting feature of the distribution of nursery areas along the east coast of southern Africa is that secondary nursery areas of tropical species often extend further into subtropical regions than do the primary nursery areas. By primary nursery areas is meant those where the young sharks are actually born and spend the first part of their lives. Secondary areas are those inhabited by the slightly older but not yet adolescent or mature sharks.'

(Bass 1978, p. 579)

Although somewhat ambiguous, the delineation of primary and secondary nurseries by Bass (1978) reflects a more realistic view of most shark populations than provided by Springer's (1967) generalized description. Bass's (1978) primary nursery areas are in essence the area where females give birth or lay eggs, while the secondary areas are those in which juveniles spend the ensuing years as they grow towards maturity.

In a review of the early life history characteristics of northwest Atlantic Ocean carcharhinoid and lamnoid sharks, Branstetter (1990) commented on the utility of nursery areas for juvenile shark growth and survival. He suggested that food is unlikely to be a limiting resource for juvenile sharks since nurseries are typically found in areas of high productivity that would provide ample food for these opportunistic feeders. Instead, he suggested that predation risk is a much greater concern for young sharks within coastal waters and identified 2 further types of nursery area:

'The nursery grounds can be categorized by their degree of exposure to potential predators. Some are 'protected,' because they are in areas infrequently inhabited by adult sharks, while others are very 'unprotected,' because they are located in habitats occupied by adults.' $\quad$ (Branstetter 1990, p. 18)

Branstetter (1990) recognized that the degree of protection afforded by nursery areas can be variable, and also that as such they represent a component of the life history of a species. We shall return to both of these concepts later.

In 1993, field surveys on sharks in US and Australian bays reported that multiple species use the same location as potential nursery areas. Castro (1993) reported 9 species of shark utilizing Bull's Bay on the US east coast as a nursery area, and Simpfendorfer \& Milward (1993) reported 8 species utilizing Cleveland Bay on Queensland's east coast. Simpfendorfer \& Milward (1993) referred to these locations as 'communal nurseries' and suggested that these shared nursery areas may have increased evolutionary benefits by reducing inter-specific and intra-specific predation. Castro (1993) also described the organization of shark nurseries in some detail from observations made in Bulls Bay, South Carolina. This described how seasonal migrations, mediated mostly by changes in water temperature, may result in a species having geographically separate summer and winter nurseries. This concept appears to overlap with Bass's description of primary and secondary nursery areas when he described how secondary nursery areas were often in more temperate regions.

\section{FIELD STUDIES}

Concurrent with (and subsequent to) publications that dealt with the shark nursery area concept, there have been numerous studies that have examined shark nursery areas. These can be divided into 2 categories. Firstly, there are those that that have aimed to identify and map nursery areas. These studies have mostly taken a survey approach to determine the presence of juvenile sharks in specific regions, often in response to informational needs for the development of management plans (e.g. Snelson \& Williams 1981, Castro 1993, Simpfendorfer \& Milward 1993, Thorpe et al. 2004, Parsons \& Hoffmayer 2005, Saïdi et al. 2005, Blackburn et al. in press, Gurshin in press, Neer et al. in press, Merson \& Pratt in press, Parsons \& Hoffmayer in press). The second type of study has aimed to better understand the function of nursery areas by investigating the ecology of juvenile sharks and the habitats in which they occur. These detailed ecological studies have often been undertaken over extended periods in locations identified as potential nursery areas for specific species. For example, sandbar sharks Carcharhinus plumbeus in the Chesapeake Bay-Delaware Bay region (e.g. Medved \& Marshall 1983, Wetherbee \& Rechisky 2000, Merson \& Pratt 2001, Rechisky \& Wetherbee 2003, Grubbs \& Musick in press, Grubbs et al. in press), lemon sharks Negaprion brevirostris at Bimini, Bahamas (e.g. Gruber et al. 1988, Morrissey \& Gruber 1993a,b, Gruber et al. 2001, Sundström et al. 2001, Clermont-Edrén \& Gruber 2005), scalloped hammerhead sharks Sphyrna lewini in Kaneohe Bay, Hawaii (e.g. Clarke 1971, Holland et al. 1993, Bush \& Holland 2002, Lowe 2002, Bush 2003, Duncan \& Holland 2006), sympatric coastal sharks (several taxa) in northwest Florida (e.g. Carlson \& Brusher 1999, Carlson 2002, Bethea et al. 2004, Bethea et al. 2006), and blacktip sharks Carcharhinus limbatus in central west Florida (e.g. Heupel \& Hueter 2001, 2002, Hueter \& Tyminski 2002, Heupel et al. 2004, Heupel \& Simpfendorfer 2005, Heupel in press). In other instances isolated ecological studies have occurred (e.g. 
Williams \& Schaap 1993, Stevens \& West 1997). These ecological studies have provided data to further refine the concept of shark nursery areas.

Despite all of this research, there has been relatively little change in the shark nursery area paradigm since it was first elucidated. As a result there is still a limited view of what a shark nursery area actually consists of, or how one can be defined. Few studies have specifically tested hypotheses on the quality of a proposed nursery habitat or areas. Most authors still suggest these regions must benefit the young by providing ample food resources and protection from predation based on the early conceptual work of Springer (1967), Bass (1978), Branstetter (1990) and others. However, questions still arise about this current paradigm of shark nursery areas:

- Can this paradigm be used as a definition for a shark nursery area (i.e. a region providing abundant food and reduced risk of predation as compared to other regions) and can it be used to delineate habitats or regions of critical importance during early life stage(s)?

- Does this paradigm equip current and future researchers with a clear enough definition to use the term appropriately and consistently in scientific research (i.e. for hypothesis testing) and in presentations and publications?

- Finally, given what has been published in the 40 years since the Springer (1967) description of a hypothetical population, is there a need for a change in the shark nursery area paradigm, and can we do any better at defining this term than those who have done so before us?

\section{WHAT CONSTITUTES A SHARK NURSERY AREA?}

A 'nursery' is defined as 'something that fosters, develops or promotes' and 'a place where animals are cared for' (Babcock 1993). Such a definition undoubtedly formed the basis for the development of the nursery area concept for sharks (e.g. Springer 1967, Bass 1978, Branstetter 1990). However, early work on this subject was based on observations from researchers who had spent many years working with sharks and who summarized their observations into a simple concept that could be applied broadly. This has provided a detailed background to the problem, but this background has been poorly supported by empirical studies designed to test the benefits of specific areas to shark populations.

Scientists and resource managers have concluded that nursery areas must benefit the population as a whole and have expended considerable resources and effort in mapping and identifying them. However, there is a paucity of data on exactly what constitutes a shark nursery and as a result a fairly broad or liberal interpretation has been given to the largely observational work (i.e. Springer 1967, Bass 1978, Branstetter 1990, Castro 1993). Many of these studies have failed to provide compelling evidence that such areas provide a nurturing function for the juvenile sharks that ultimately contribute to the adult population. For example, Simpfendorfer \& Milward (1993) concluded that Cleveland Bay on the Queensland coast was a nursery area for at least 8 species based purely on the occurrence of neonate or juvenile specimens in surveys. They provided limited information to support the concept that this area provided any advantages to the populations. Many other current and previous research efforts that have identified and mapped nursery areas have similarly defined nursery regions based on the presence of juvenile individuals and little else, e.g. Castro 1993, Thorpe et al. 2004, Blackburn et al. in press, Merson \& Pratt in press. As such, vast tracts of coastal bays and estuaries have now been identified as nursery areas based simply on the fact that juvenile sharks were observed there. The risk with this approach is that with such broad areas being defined as nurseries, the ability to conserve habitatespecially the most valuable habitats - is diluted (Beck et al. 2001). This has lead to growing concern that protecting areas for juvenile sharks is unrealistic since they cover such a large amount of ocean.

One factor that makes the delineation of shark nursery areas difficult is the mobility of many sharks, even while young. The precocious nature of newborn sharks means that they are normally mobile, have relatively large home ranges (e.g. Holland et al. 1993, Morrissey \& Gruber 1993a, Wetherbee \& Rechisky 2000, Merson \& Pratt 2001, Heupel et al. 2004) and typically occur in a range of habitats (e.g. Castro 1993, Holland et al. 1993, Morrissey \& Gruber 1993a, Grubbs \& Musick 2002, McCandless et al. 2002). This is not to say that they do not have relatively high levels of site fidelity, just that they are less likely to be constrained to individual habitat types in the way many teleost and invertebrate species are (Beck et al. 2001). This limits our ability to describe a specific habitat as being typical of shark nursery areas. In addition, sharks can move out of one potential nursery area to new regions which may, or may not, act as nurseries.

\section{ASSUMPTIONS}

In the 40 years since the publication of Springer (1967) on the social organization of shark populations, several aspects of the shark nursery area concept have become accepted as fact, even though they have 
rarely, if ever, been thoroughly tested. These assumptions have resulted from the vague nature of the current definition of shark nursery areas and from the lag between the development of theory and the collection of data to test it. Here we examine a number of these assumptions and the evidence for or against them in an attempt to help further the development of the shark nursery area concept.

\section{All sharks have nursery areas}

The vague definition in the literature, where the occurrence of juveniles is the only criterion for identifying a nursery, has meant that all shark species would be considered to have a nursery or nurseries. Such a definition, however, is increasingly out of step with the nursery concepts for other groups of aquatic organisms, where definitions such as that of Beck et al. (2001) have been adopted. With stricter definitions there will be fewer areas identified as shark nurseries, and some species may have no nursery areas at all. This concept is consistent with the observations of Springer (1967) who noted that some species do not have defined nursery areas, e.g. tiger shark Galleocerdo cuvier. There is also variation in the occurrence of potential nursery areas between stocks of the same species. For example, sandbar shark nursery areas have been documented in bays along the east coast of the United States (Grubbs \& Musick in press, Grubbs et al. in press), while off Western Australia the young occur offshore and appear to not have a distinct nursery area (McAuley et al. in press). McElroy et al. (2006) also found no use of bays as potential nurseries in Hawaiian waters.

With fewer areas identified as nurseries, we anticipate that the terms pupping, birthing or hatching areas will be more commonly used in the literature to indicate areas where the young are born or hatched. Unlike the present situation where all pupping areas are considered nursery areas, a stricter definition would mean that some pupping areas may be nurseries, but not all.

Rather than assume that all sharks have nursery areas, we suggest that they are one component of a shark's life history. Branstetter (1990) introduced this concept and suggested that there was a relatively complex trade-off relationship between this and other life history components. In addition to nursery areas, sizeat-birth, rate of growth, time to maturity, litter size and frequency of breeding are probably important factors in life history strategy trade-offs with nursery areas.

It is often assumed that sharks with a small size-atbirth would benefit from protected nursery areas as it would increase their chance of survival and so con- tribute to recruitment into the adult population. However, several species of small coastal sharks with small sizes at birth appear not to have nursery areas. For example, blacknose sharks Carcharhinus acronotus give birth in a wide variety of coastal habitats, from shallow coastal bays (Carlson 2002) to open beaches where large predators are known to be present (C. A. Simpfendorfer unpubl. data). Based on the small size of blacknose shark pups (ca. $29 \mathrm{~cm}$ TL) it would seem logical for these newborn sharks to occupy some form of protected habitat as a means of avoiding predation. Similarly, Atlantic sharpnose sharks Rhizoprionodon terraenovae which are among the smallest of coastal species are born offshore, recruit to coastal bays in spring (Carlson 2002, Parsons \& Hoffmayer 2005) and then appear to move throughout adjacent coastal habitats during summer (J. K. Carlson \& M. R. Heupel unpubl. data). Movements among adjacent bays would theoretically expose these sharks to higher predation than would be afforded if individuals remained within confined, shallow regions. These small coastal sharks are species that have relatively productive life history strategies (i.e. rapid growth, early maturity, annual reproduction etc.) and high rates of population growth (see Cortés 2002 for a review) when compared to other shark species. Given a life history that is relatively tolerant of juvenile mortality, the benefits of nursery areas for these species may be limited.

For species that have small size at birth and slow juvenile growth rates the opposite is probably true (i.e. they may be more likely to have nursery areas), since the population would be more susceptible to higher juvenile mortality. One example of a shark with this type of life history strategy is the school shark Galeorhinus galeus. Olsen (1954) identified a number of areas for this species in eastern Tasmania and Victoria, Australia, where high densities of newborn animals were regularly observed. The life history of school sharks includes a small size at birth (33 to $35 \mathrm{~cm}$, Compagno 1984), slow growth (von Bertalanffy $K=0.124$ ) and late maturity (ca. 8 yr, Moulton et al. 1992). Based on these life history characteristics this species may directly benefit from the use of nursery areas.

Trade-offs between life history components would also suggest a species that has protected nursery areas may be predicted to have fewer young and have longer periods between reproductive events since the young should have higher survival rates. Support for this hypothesis comes from the blacktip shark Carcharhinus limbatus, which has some well defined nursery areas (Heupel \& Hueter 2002, Hueter \& Tyminski 2002, Keeney et al. 2003, Heupel et al. 2004, Heupel \& Simpfendorfer 2005). This species has relatively small litters (4 to 6 pups) and females produce litters every 2 yr after reaching maturity (Castro 1996). 
The above examples demonstrate that nursery areas are potentially traded-off with other components of the life history strategy of sharks. It follows that only those species for which nursery areas provide some increase in production are likely to benefit from using them. At the very least, there will be different levels of nursery area use. However, we suggest that further research is needed to help with the identification of habitats as nurseries: this would involve improved definition of attributes of habitat that enable increases in production. Given that reduced predation risk is unlikely to be a factor in the increase in production for unprotected nurseries, other factors such as those that increase rates of growth (e.g. abundant food, optimal temperatures) and reduce time spent at vulnerable smaller sizes may be more important. In some cases it may be found that areas considered to be 'unprotected nurseries' do not increase production and so are not nurseries at all.

The need to better define shark nursery areas and to apply testable criteria will require the shark research community to provide greater proof when reporting nursery areas. Not all species will have nursery areas, and not all areas where juvenile sharks occur will be nursery areas. This will help focus conservation and management efforts for nursery areas on those that provide the greatest value to the populations. This will also allow better definition of birthing and hatching areas, providing additional information for management of these areas as needed.

\section{Nursery areas provide ample resources for juvenile sharks}

Conventional shark nursery area theory assumes that nursery areas provide the most advantageous habitat for the growth and survival of young sharks by being in productive areas and having an abundant supply of food. While this concept is intuitively sensible, field studies are drawing this assumption into question. Lowe (2002) reported low energetic condition of neonate scalloped hammerhead sharks Sphyrna lewini in Kaneohe Bay, Hawaii. Using respirometry, tracking and a bioenergetic model he calculated that in the first summer after birth many individuals did not consume enough food to maintain a constant growth rate. As a result, he hypothesized that a substantial proportion of these animals die from starvation. Bush (2003) also demonstrated that food consumption rates in Kaneohe Bay were below those estimated by Lowe (2002) to meet energetic demands. Duncan \& Holland (2006) demonstrated that weight and condition factor declined in $S$. lewini during their first summer. Lowe (2002) attributed this phenomenon to the low calorific value of their main prey types and intense competition for food with congeners immediately after birth. Bush \& Holland (2002) hypothesized that this food limitation may be unique to this location because of the limited productivity of the island ecosystem. However, more recently, similar situations have been reported for young-of-the-year bonnethead (Carlson et al. 2004) and Atlantic sharpnose sharks (Hoffmayer et al. 2006) in the northern Gulf of Mexico. While Atlantic sharpnose sharks may not have nursery areas, and it is doubtful for bonnethead sharks, these studies clearly demonstrate that newborn sharks may be more food limited than previously contended by nursery area studies.

Sympatric species of sharks are often found simultaneously occupying a proposed nursery (i.e. the communal nursery of Simpfendorfer \& Milward 1993). One disadvantage of several species utilizing the same nursery area is the increased chance of competition. However, Bethea et al. (2004) found that moderate overlap in diet resources was offset by low overlap in habitat use by 4 species of sharks in Apalachicola Bay, Florida. If diet resources are limiting in this bay, then sharks may distribute themselves on different spatial and temporal scales to reduce competition pressure. Further evidence indicates that in some habitats juveniles do not distribute themselves in relation to food abundance. Juvenile blacktip shark movement patterns and habitat use were more consistent with predator avoidance than with prey distribution (Heupel \& Hueter 2002, Heupel \& Simpfendorfer 2005). Thus although some putative nursery areas are highly productive, it seems likely that some shark species are selecting these habitats based more on predator avoidance trading-off against food consumption. This observation is consistent with the theoretical considerations of Heithaus (in press) that individuals may select habitats based on trade-offs between food availability and predation risk.

The preponderance of food in nursery areas that has for decades been a central tenet of the shark nursery concept therefore appears to be in question. While some nurseries may have ample food resources, food limitation does occur in others. Further research to investigate if food limitation occurs in the nursery areas of other species is required to determine how wide-spread this phenomenon is. Research to investigate the causes of food limitation may also reveal new insights into the functioning of nursery areas and the advantages they provide. These studies should also consider historical aspects of the habitat where possible. Many coastal habitats have been altered, harvested or degraded. Human use of these regions may have changed their dynamics. If sharks are philopatric to these regions (e.g. Hueter et al. 2005) they may con- 
tinue to use a region that was historically a good nursery, but at present does not provide the benefits it once held.

\section{Nursery areas reduce predation risk and therefore have low mortality rates}

The assumption that shark nursery areas provide protection from predation should lead to the prediction that natural mortality rates of juveniles within these habitats are low compared to rates in non-nursery areas. Data concerning survival rates of young sharks, however, are very limited and are often based on life history correlations (e.g. Cortés 2002, Simpfendorfer et al. 2005a). In addition, if a species is known to use nursery areas as a means to reduce mortality it is often difficult to determine what the mortality rate, would be outside the nursery because of their mobility, which may make apportioning mortality to a specific site or habitat complex. Despite this, some data on the mortality rate of sharks in proposed nursery areas are available. Analysis of acoustic monitoring data of juvenile blacktip sharks within Terra Ceia Bay, Florida, revealed natural mortality rates of 32 to $70 \%$ in the first 15 wk of summer (Heupel \& Simpfendorfer 2002). Similarly, Manire \& Gruber (1993) estimated 44 to $61 \%$ and Gruber et al. (2001) reported 35 to $62 \%$ of neonate lemon sharks Negaprion brevirostris born at Bimini, Bahamas, died in their first year. These mortality rates suggest that nursery areas may not always provide sufficient resources or protection from predation. The importance of predation as opposed to food limitation, which may result in starvation (see above), cannot easily be determined and awaits further research. However, a multi-year study of the lemon shark nurseries in Bimini has revealed no evidence for starvation and so mortality in these areas is likely to be the result of predation (S. Gruber pers. comm.).

Mortality rates of some young sharks, however, appear to be considerably lower than those estimated for blacktip and lemon sharks. For example, only 4 of 55 individual young-of-the-year bull sharks Carcharhinus leucas suffered mortality over a 3 yr period (M.R. Heupel unpubl. data). This low level of mortality may be the result of bull sharks utilizing rivers where salinity is below those that are tolerated by other shark species and potential predators (Simpfendorfer et al. 2005b). Thus there appears to be at least some areas that produce very low rates of mortality, possibly due to low rates of predation.

An extension of this assumption is that adult sharks (i.e. predators) are not present or are present in only relatively small numbers within nursery areas. Although nursery areas are often geographically dis- crete from adult habitat for one species, proposed nurseries are commonly located in areas frequented by large individuals of other species. For example, Pine Island Sound, Charlotte Harbor, and Apalachicola Bay, Florida could be documented as potential blacktip shark nursery areas (Carlson 2002, Hueter \& Tyminski 2002). These areas are known to have high densities of newborn blacktip sharks (measured as a standardized catch-per-unit effort) over many years, compared to lower densities in adjacent habitats. Although these areas are relatively shallow estuaries $(<4.0 \mathrm{~m}$ deep) they are large systems and are inhabited by juvenile and adult bull, great hammerhead, and lemon sharks (J. Carlson unpubl. data, M.R. Heupel unpubl. data). The continuous presence (inferred from acoustic and satellite monitoring data) of larger sharks known to prey on elasmobranchs suggests that newborn blacktip sharks are exposed to predation within these potential nurseries. Whether juvenile blacktip sharks employ strategies to avoid predators within the nursery is currently poorly understood. Based on ecological theory Heithaus (in press) suggested that juvenile sharks should aggregate to avoid predators if foraging times were short. Aggregation behavior was reported for naïve populations of neonate blacktip sharks over 3 consecutive years within a nursery area (Heupel \& Simpfendorfer 2005) suggesting that this is a natural behavior for some species of sharks and therefore that predation affects movement patterns and habitat use within a nursery area. If predation risk was only a minor concern for these individuals it seems unlikely that their behavior patterns would focus on predator avoidance.

More research is required to fully understand the role that predation plays in nursery areas. As previously discussed, some species may trade low food availability and hence high starvation risk, for lower predation rates. Studies that manipulate predator levels within nursery areas would especially increase our understanding of how juvenile sharks modify their behavior to avoid predators, and how natural mortality is partitioned among starvation, predation and other sources.

\section{Primary nursery areas overlap with secondary nursery areas}

The concept of primary and secondary nursery areas is a difficult one to define. The original description by Bass (1978) is not detailed enough to provide clarity. Careful examination of Bass (1978) reveals that his original description implied 2 geographically discrete regions (note that 'Natal' is referring to the South African province): 
'An example of this phenomenon is shown by Carcharhinus plumbeus. Immature C. plumbeus of 90 to $160 \mathrm{~cm}$ are fairly common in Natal waters, but newborn specimens (60 to $65 \mathrm{~cm}$ in length) are completely absent.'

(Bass 1978, p. 579)

Bass (1978) also stated that newborn sharks move from the primary nursery to the secondary nursery, and reported evidence from at least 5 other species along the African coast. Therefore descriptions of overlapping primary and secondary nursery areas appear to contradict the original definition. Secondary nursery areas are currently interpreted as regions where older (non-newborn) sharks occur regardless of whether newborns are present or not (see McCandless et al. 2002). Therefore, current usage of this term allows direct geographic overlap of primary and secondary nursery areas.

Although this seems like a minor distinction, Bass (1978) stated that individuals of different size classes were not sharing habitat and must have moved from one region to another. The limited definition provided by Bass (1978) leaves it to the reader to interpret the definition of these regions. If an individual is born in a nursery area (therefore primary nursery), migrates away for the winter and returns to the natal nursery as a 1 or 2 yr old individual, does that mean this is also a secondary nursery? If so, is it useful to have 2 classifications for the same region? What if, as in the case of some tropical species, sharks remain within the primary nursery for a period of several years? Is the region then both a primary and secondary nursery if individuals never left the primary nursery? The complex and variable nature of shark life history strategies makes it difficult to apply the term secondary nursery to these populations in a uniform manner.

On the opposite side of this issue is the fact that individuals of some species leave the primary nursery for the winter and may then utilize a different area in the following summer that may be $>100 \mathrm{~km}$ away from the primary nursery. Is the new region a secondary nursery? If this area is labeled as a secondary nursery then highly dispersed sharks will result in large tracts of coastline being labeled as nursery. This labeling dilutes the effectiveness of defining a nursery and clouds the issue for management purposes. It is critical that a common definition be determined for these regions and that terminology is standardized. If this fails to happen, the applicability of these data for conservation and management is severely diminished.

Based on the ambiguity of the original definition put forth by Bass (1978) and observations of tropical species remaining within nurseries for periods of several years (Castro 1993, Heupel unpubl. data), it seems inappropriate to attempt to apply qualifiers to those regions. Therefore we propose elimination of the terms primary and secondary nursery as observed by Bass (1978). We suggest that regions containing newborn and juvenile sharks be limited in description and simply referred to as nursery areas providing they meet the criteria proposed herein. The distinction between primary and secondary nurseries awaits a more suitable scientifically acceptable definition.

\section{PROPOSED DEFINITION}

It is our contention that the occurrence of juvenile sharks in an area is insufficient evidence to proclaim it a nursery. Such a liberal definition does not demonstrate the value of a habitat or region to a population, and would probably result in most coastal areas being identified as shark nurseries. If we assume that Beck et al.'s (2001) assertion is correct, then juveniles produced in nursery area habitat should have increased production relative to those from other non-nursery habitats, since these individuals will be more likely to end up in the reproductive population. Such an assumption should result in 2 phenomena. First, natal homing and philopatry would more than likely occur and so these habitats would be used year after year. Although there is limited data regarding these phenomena in sharks there is increasing evidence that it occurs (Hueter et al. 2005). For example, Keeney et al. (2003) provided genetic evidence that Carcharhinus limbatus is philopatric, at least to broad coastal bays. Second, there would be a tendency for individuals to have a high level of site fidelity to these areas because these areas have the ability to increase production. Thus it is possible to define a nursery on the basis of a species' abundance, residency and inter-annual use.

We suggest that a shark nursery area could be defined based on 3 primary criteria for newborn or young-of-the-year (i.e. individuals <1 yr old): (1) sharks are more commonly encountered in the area than in other areas, i.e. density in the area is greater than the mean density over all areas, (2) sharks have a tendency to remain or return for extended periods (weeks or months), i.e. site fidelity is greater than the mean site fidelity for all areas, (3) the area or habitat is repeatedly used across years, whereas others are not.

This proposed definition does not discount the importance of other factors identified previously by research, such as food abundance or refuge from predators. Instead it provides researchers and resource managers a definition that can be tested in a straightforward manner using data collected in the field.

These proposed criteria remove much of the ambiguity that exists in many published shark nursery studies. The necessity of encountering a relatively large number of individuals that remain within the area and use it over 
multiple years increases the amount of information that is required to demonstrate an area is a nursery and would discount some that are currently considered nursery areas. For example, if a group of sharks are captured together off a beach en route to their winter grounds, this area would not be considered a nursery since there is no residency (i.e. site fidelity) in the area. However, given the criteria used in many past and current studies, the area would be considered a nursery area. This is not to discount the potential importance of this habitat as a migratory corridor, but we argue that there is no evidence that the area is providing a nursery function.

The more rigorous nursery area definition set forth by Beck et al. (2001) has proven difficult to implement; we believe our definition can be more easily used to define and test whether a region qualifies as a shark nursery. Currently available techniques can be used to determine if an area meets the criteria. Scientific surveys can be designed to quantify the number of sharks in all possible regions both within and between years assuming juvenile habitats are surveyed simultaneously (Criteria $1 \& 3$ ). Shark residency within a region (Criterion 2) can be tested using mark-recapture studies, acoustic tracking, stable isotope analysis or acoustic monitoring. These approaches could also be taken to examine use of nursery habitats in subsequent years (philopatry) via recapture of individuals from previous years. Re-use of natal areas would further emphasize the importance of that habitat or region by showing that individuals from multiple year classes depend on that habitat. Genetic techniques can also provide supporting data by demonstrating the occurrence of phenomena such as philopatry (Criterion 3), e.g. Keeney et al. (2003). The ability to identify shark nursery areas using this new definition is therefore at hand and could be readily applied to identify those areas that truly act as nurseries for sharks.

\section{CONCLUSIONS}

In the century since shark nursery areas were recognized in the scientific literature there has been a single paradigm, first enunciated by Springer (1967), where the young are born in a region separated from the adults that has abundant food and low predation risk. While this paradigm is intuitive, it does not provide a clear way to identify whether a particular region or habitat is a nursery area. As a result it has become the norm that a shark nursery area is one where juvenile sharks occur.

Based on data that has become available in recent years the basic assumptions regarding shark nursery areas have been challenged, signaling a need for a change in the paradigm. This shift in the shark nursery area paradigm may trouble some researchers and resource managers. However, if science is to keep pace with the needs of resource management and our growing understanding of nursery areas, this shift is essential. We hope that this paper will lead to a period of transition, during which the merits of criteria for identifying shark nurseries are debated and sound science to support them is undertaken. Such a transition should allow the emergence of a new paradigm on the concept of shark nursery, forming the basis for improved management of these areas and for further research and monitoring.

Acknowledgements. We thank J. Bass and S. Gruber for information pertaining to this manuscript and P. Sheridan for valuable comments on an earlier draft.

\section{LITERATURE CITED}

Babcock GP (ed) (1993) Websters third new international dictionary of the English language-unabridged. Merriam Webster, Springfield, MA

Bass AJ (1978) Problems in studies of sharks in the Southwest Indian Ocean. In: Hodgson ES, Mathewson RF (eds) Sensory biology of sharks, skates and rays. Office of Naval Research, Department of the Navy, Arlington, VA, p 545-594

Bass AJ, D'Aubrey JD, Kistnasamy N (1973) Sharks of the east coast of southern Africa. I. The genus Carcharhinus (Carcharhinidae). Invest Rep Oceanogr Res Inst 33:1-168

Bass AJ, D'Aubrey JD, Kistnasamy N (1975) Sharks of the east coast of southern Africa. III. The families Carcharhinidae (excluding Mustelus and Carcharhinus) and Sphyrnidae. Invest Rep Oceanogr Res Inst 38:1-100

Beck MW, Heck KL, Able KW, Childers DL and 9 others (2001) The identification, conservation, and management of estuarine and marine nurseries for fish and invertebrates. BioScience 51:633-641

Bethea DM, Buckel JA, Carlson JK (2004) Foraging ecology of the early life stages of four sympatric shark species. Mar Ecol Prog Ser 268:245-264

Bethea DM, Carlson JK, Buckel JA, Satterwhite M (2006) Ontogenetic and site-related trends in the diet of the Atlantic sharpnose shark Rhizoprionodon terraenovae from the northeast Gulf of Mexico. Bull Mar Sci 78: $278-307$

Blackburn JK, Neer JA, Thompson BA (in press) Delineation of bull shark nursery areas in the inland and coastal waters of Louisiana. In: McCandless CT, Pratt HL Jr, Kohler NE (eds) Shark nursery grounds of the Gulf of Mexico and east coast waters of the United States. American Fisheries Society Symposium, Bethesda, MD

Branstetter S (1990) Early life-history implications of selected carcharhinoid and lamnoid sharks of the northwest Atlantic. In: Pratt HL Jr, Gruber SH, Taniuchi T (eds) Elasmobranchs as living resources: advances in biology, ecology, systematics and the status of the fisheries. NOAA Tech Rep 90, National Marine Fisheries Service, Silver Spring, MD, p 17-28

Bush A (2003) Diet and diel feeding periodicity of juvenile scalloped hammerhead sharks, Sphyrna lewini, in Kane'ohe Bay, O'ahu, Hawai'i. Environ Biol Fish 67:1-11 
Bush A, Holland K (2002) Food limitation in a nursery area: estimates of daily ration in juvenile scalloped hammerheads, Sphyrna lewini (Griffith and Smith, 1834) in Kane'ohe Bay, O'ahu, Hawai'i. J Exp Mar Biol Ecol 278: $157-178$

Carlson JK (2002) Shark nurseries in the northeastern Gulf of Mexico. In: McCandless CT, Pratt HL Jr, Kohler NE (eds) Shark nursery grounds of the Gulf of Mexico and East Coast waters of the United States: an overview. An internal report to NOAA's Highly Migratory Species Office. NOAA Fisheries, Narragansett, RI, p 165-182

Carlson JK, Brusher JH (1999) An index of abundance for coastal species of juvenile sharks from the northeast Gulf of Mexico. Mar Fish Rev 61:37-45

Carlson JK, Goldman KJ, Lowe C (2004) Metabolism, energetic demand, and endothermy. In: Carrier J, Musick J, Heithaus $M$ (eds) The biology of sharks and their relatives. CRC Press LLC, Boca Raton, FL, p 203-224

Castro JI (1993) The shark nursery of Bulls Bay, South Carolina, with a review of the shark nurseries of the southeastern coast of the United States. Environ Biol Fish 38: $37-48$

Castro JI (1996) Biology of the blacktip shark, Carcharhinus limbatus, off the southeastern United States. Bull Mar Sci 59:508-522

Clarke TA (1971) The ecology of the scalloped hammerhead shark, Sphyrna lewini, in Hawaii. Pac Sci 25:133-144

Clermont-Edrén SM, Gruber SH (2005) Homing ability of young lemon sharks, Negaprion brevirostris. Environ Biol Fish 72:267-281

Compagno LJV (1984) FAO Species catalogue. Vol. 4. Sharks of the world: an annotated and illustrated catalogue of shark species known to date. II. Carcharhiniformes. FAO Fisheries Synopsis No. 125, FAO, Rome, p 478-481

Cortés E (2002) Incorporating uncertainty into demographic modeling: application to shark populations and their conservation. Conserv Biol 16:1048-1062

Duncan KM, Holland KN (2006) Habitat use, growth rates and dispersal patterns of juvenile scalloped hammerhead sharks Sphyrna lewini in a nursery habitat. Mar Ecol Prog Ser 312:211-221

Fowler SL, Cavanagh RD, Camhi M, Burgess GH, Cailliet GM, Fordham SV, Simpfendorfer CA, Musick JA (2005) Sharks, rays and chimeras: the status of the chondrichthyan fishes. Status survey. IUCN/SSC Shark Specialist Group, IUCN, Gland and Cambridge

Grubbs RD, Musick JA (2002) Shark nurseries of Virginia: spatial and temporal delineation, migratory patterns and habitat selection: a case study. In: McCandless CT, Pratt HL Jr, Kohler NE (eds) Shark nursery grounds of the Gulf of Mexico and east coast waters of the United States: an overview. An internal report to NOAA's Highly Migratory Species Office, NOAA Fisheries, Narragansett, RI, p 25-60

Grubbs RD, Musick JA (in press) Spatial delineation of summer nursery areas for juvenile sandbar sharks in Chesapeake Bay, Virginia. In: McCandless CT, Pratt HL Jr, Kohler NE (eds) Shark nursery grounds of the Gulf of Mexico and east coast waters of the United States. American Fisheries Society Symposium, Bethesda, MD

Grubbs RD, Musick JA, Conrath CL, Romine JG (in press) Long-term movements, migrations, and temporal delineation of a summer nursery for juvenile sandbar sharks in the Chesapeake Bay region. In: McCandless CT, Pratt HL Jr, Kohler NE (eds) Shark nursery grounds of the Gulf of Mexico and east coast waters of the United States. American Fisheries Society Symposium, Bethesda, MD
Gruber SH, Nelson DR, Morrissey JF (1988) Patterns of activity and space utilization of lemon sharks, Negaprion brevirostris, in a shallow Bahamian Lagoon. Bull Mar Sci 43: $61-76$

Gruber SH, de Marignac JRC, Hoenig JM (2001) Survival of juvenile lemon sharks at Bimini, Bahamas, estimated by mark-depletion experiments. Trans Am Fish Soc 130: 376-384

Gurshin CWD (in press) Shark nursery grounds in Sapelo Island National Estuarine Research Reserve, Georgia. In: McCandless CT, Pratt HL Jr, Kohler NE (eds) Shark nursery grounds of the Gulf of Mexico and east coast waters of the United States. American Fisheries Society Symposium, Bethesda, MD

Heck KL Jr, Hays G, Orth RJ (2003) Critical evaluation of the nursery role hypothesis for seagrass meadows. Mar Ecol Prog Ser 253:123-136

Heithaus MR (in press) Nursery areas as essential shark habitats: a theoretical perspective. In: McCandless CT, Pratt HL Jr, Kohler NE (eds) Shark nursery grounds of the Gulf of Mexico and east coast waters of the United States. American Fisheries Society Symposium, Bethesda, MD

Heupel MR (in press) Exiting Terra Ceia Bay: examination of cues stimulating migration from a summer nursery area. In: McCandless CT, Pratt HL Jr, Kohler NE (eds) Shark nursery grounds of the Gulf of Mexico and East Coast waters of the United States. American Fisheries Society Symposium, Bethesda, MD

Heupel MR, Hueter RE (2001) Use of an automated acoustic telemetry system to passively track juvenile blacktip shark movements. In: Sibert JR, Nielsen JL (eds) Electronic tagging and tracking in marine fisheries. Kluwer, Dordrecht, p 217-236

Heupel MR, Hueter RE (2002) The importance of prey density in relation to the movement patterns of juvenile sharks within a coastal nursery area. Mar Freshw Res 53:543-550

Heupel MR, Simpfendorfer CA (2002) Estimation of survival and mortality of juvenile blacktip sharks, Carcharhinus limbatus, within a nursery area using telemetry data. Can J Fish Aquat Sci 59:624-632

Heupel MR, Simpfendorfer CA (2005) Quantitative analysis of shark aggregation behavior. Mar Biol 147:1239-1249

Heupel MR, Simpfendorfer CA, Hueter RE (2004) Estimation of shark home ranges using passive monitoring techniques. Environ Biol Fish 71:135-142

Hoffmayer ER, Parsons GR, Horton J (2006) Seasonal and inter-annual variation in the energetic condition of the adult male Atlantic sharpnose shark, Rhizoprionodon terraenovae, in the northern Gulf of Mexico. J Fish Biol 68: 645-653

Holland KN, Wetherbee BM, Peterson JD, Lowe CG (1993) Movements and distribution of hammerhead shark pups on their natal grounds. Copeia 1993:495-502

Hueter RE, Tyminski JT (2002) Center for Shark Research (CSR) U.S. shark nursery research overview 1991-2001. In: McCandless CT, Pratt HL Jr, Kohler NE (eds) Shark nursery grounds of the Gulf of Mexico and East Coast waters of the United States: an overview. An internal report to NOAA's Highly Migratory Species Office, NOAA Fisheries, Narragansett, RI, p 116-135

Hueter RE, Heupel MR, Heist EJ, Keeney DB (2005) The implications of philopatry in sharks for the management of shark fisheries. J Northwest Atl Fish Sci 35:239-247

Keeney DB, Heupel MR, Hueter RE, Heist EJ (2003) Genetic evidence of stock structure among blacktip shark, Carcharhinus limbatus, continental nurseries along the U.S. Atlantic and Gulf of Mexico. Mar Biol 143:1039-1046 
Kraus RT, Secor DH (2005) Application of the nursery-role hypothesis to an estuarine fish. Mar Ecol Prog Ser 291: 301-305

Lowe CG (2002) Bioenergetics of free-ranging juvenile scalloped hammerhead sharks (Sphyrna lewini) in Kāne'ohe Bay, Ōahu, HI. J Exp Mar Biol Ecol 278:141-156

Manire CA, Gruber SH (1993) A preliminary estimate of natural mortality of age-0 lemon sharks, Negaprion brevirostris. Tech 115:65-71, Rep NOAA, Silver Spring, MD

McAuley RB, Simpfendorfer CA, Hyndes GA, Lenanton RCJ (2007) Distribution and reproductive biology of the sandbar shark, Carcharhinus plumbeus (Nardo), in Western Australian waters. Mar Freshw Res 58:116-126

McCandless CT, Pratt HL Jr, Kohler NE (2002) (eds) Shark nursery grounds of the Gulf of Mexico and east coast waters of the United States: an overview. An internal report to NOAA's Highly Migratory Species Office. NOAA Fisheries, Narragansett, RI

McCandless CT, Pratt HL Jr, Kohler NE (eds) (in press) Shark nursery grounds of the Gulf of Mexico and east coast waters of the United States. American Fisheries Society Symposium, Bethesda, MD

McElroy WD, Wetherbee BM, Mostello CS, Lowe CG, Crow GL, Wass C (2006) Food habits and ontogenetic changes in the diet of the sandbar shark, Carcharhinus plumbeus, in Hawaii. Environ Biol Fish 76:81-92

Medved RJ, Marshall JA (1983) Short-term movements of young sandbar sharks, Carcharhinus plumbeus (Pisces, Carcharhinidae). Bull Mar Sci 33:87-93

Merson RR, Pratt HL Jr (2001) Distribution, movements and growth of young sandbar sharks, Carcharhinus plumbeus, in the nursery grounds of Delaware Bay. Environ Biol Fish 61:13-24

Merson RR, Pratt HL Jr (in press) Sandbar shark nurseries in New Jersey and New York: evidence of northern pupping grounds along the United States east coast. In: McCandless CT, Pratt HL Jr, Kohler NE (eds) Shark nursery grounds of the Gulf of Mexico and East Coast waters of the United States. American Fisheries Society Symposium, Bethesda, MD

Meek A (1916) The migrations of fish. Edward Arnold, London

Morrissey JF, Gruber SH (1993a) Home range of juvenile lemon sharks, Negaprion brevirostris. Copeia 1993: 425-434

Morrissey JF, Gruber SH (1993b) Habitat selection by juvenile lemon sharks, Negaprion brevirostris. Environ Biol Fish 38:311-319

Moulton PL, Walker TI, Saddler SR (1992) Age and growth studies of gummy shark, Mustelus antarcticus Günther, and school shark, Galeorhinus galeus (Linnaeus), from southern Australian waters. Aust J Mar Freshw Res 43: 1241-1267

Neer JA, Blackburn JK, Thompson BA (in press) Shark nursery areas of central Louisiana's near shore coastal waters. In: McCandless CT, Pratt HL Jr, Kohler NE (eds) Shark nursery grounds of the Gulf of Mexico and east coast waters of the United States. American Fisheries Society Symposium, Bethesda, MD

NMFS (National Marine Fisheries Service) (2006) SEDAR 11 stock assessment report. Large coastal complex, blacktip, and sandbar shark. NOAA Highly Migratory Species Division, Silver Spring, MD

NOAA (1996) Magnusen-Stevens fishery conservation and management act, as amended through Oct. 11, 1996. NOAA Tech Memo NMFS-F/SPO-23, National Marine Fisheries Service, Silver Spring, MD
Olsen AM (1954) Tagging of school shark, Galeorhinus australis (Macleay) (Carcharhanidae), in south-eastern Australian waters. Aust J Mar Freshw Res 4:95-109

Parsons GR, Hoffmayer ER (2005) Seasonal changes in the distribution and relative abundance of the Atlantic sharpnose shark Rhizoprionodon terraenovae in the north central Gulf of Mexico. Copeia 2005:914-920

Parson GR, Hoffmayer ER (in press) Identification and characterization of shark nursery grounds along the Mississippi and Alabama Gulf coasts. In: McCandless CT, Pratt HL Jr, Kohler NE (eds) Shark nursery grounds of the Gulf of Mexico and east coast waters of the United States. American Fisheries Society Symposium, Bethesda, MD

Rechisky EL, Wetherbee BM (2003) Short-term movements of juvenile and neonate sandbar sharks, Carcharhinus plumbeus, on their nursery grounds in Delaware Bay. Environ Biol Fish 68:113-128

Saïdi B, Bradaï MN, Bouaïn A, Guélorget O, Capapé C (2005) The reproductive biology of the sandbar shark, Carcharhinus plumbeus (Chondrichthyes: Carcharhinidae), from the Gulf of Gabès (southern Tunisia, central Mediterranean). Acta Adriat 46:47-62

Simpfendorfer CA, Milward NE (1993) Utilisation of a tropical bay as a nursery area by sharks of the families Carcharhinidae and Sphyrinidae. Environ Biol Fish 37:337-345

Simpfendorfer CA, Bonfil R, Latour RJ (2005a) Mortality estimation. In: Musick JA, Bonfil R (eds) Management techniques in elasmobranch fisheries. FAO Fisheries Paper 474, FAO, Rome, p 127-142

Simpfendorfer CA, Freitas GG, Wiley TR, Heupel MR (2005b) Distribution and habitat partitioning of immature bull sharks (Carcharhinus leucas) in a southwest Florida estuary. Estuaries 28:78-85

Snelson FF Jr, Williams SE (1981) Notes on the occurrence, distribution, and biology of elasmobranch fishes in the Indian River Lagoon system, Florida. Estuaries 4:110-120

Springer S (1938) Notes on the sharks of Florida. Proc Fl Acad Sci 3:9-41

Springer S (1960) Natural history of the sandbar shark, Eulamia milberti. Fish Bull 61:1-38

Springer S (1967) Social organization of shark populations. In: Gilbert PW, Mathewson RW, Rall DP (eds) Sharks, skates and rays. John Hopkins Press, Baltimore, MD, p 149-174

Stevens JD, West GJ (1997) Investigations of school and gummy shark nursery areas in south eastern Australia. Final Report to the Fisheries Research and Development Corporation, FRDC, Canberra

Stoner AW (2003) What constitutes essential nursery habitat for a marine species? A case study of habitat form and function for queen conch. Mar Ecol Prog Ser 257:275-289

Sundström LF, Gruber SH, Clermont SM, Correia JPS and 5 others (2001) Elasmobranch behavioral studies using ultrasonic telemetry with reference to the lemon shark, Negaprion brevirostris, at Bimini Island, Bahamas. Environ Biol Fish 60:225-250

Thorpe T, Jensen CF, Moser ML (2004) Relative abundance and reproductive characteristics of sharks in southeastern North Carolina coastal waters. Bull Mar Sci 74:3-20

Wetherbee BM, Rechisky EL (2000) Movement patterns of juvenile sandbar sharks on their nursery grounds in Delaware Bay. In: Eiler JH, Alcorn DJ, Neuman MR (eds) Biotelemetry 15: Proc 15th Int Symp Biotelemetry. International Society on Biotelemetry, Wagenigen, p 91-98

Williams H, Schaap AH (1992) Preliminary results of a study into the incidental mortality of sharks in gill-nets in two Tasmanian shark nursery areas. Aust J Mar Freshw Res 43:237-250 